\title{
Keterkaitan Sektor-Sektor Ekonomi Potensial di Provinsi Riau
}

\author{
RADEN RUDI ALHEMPI ${ }^{1}$, HAZNIL ZAINAL2, SRI YANI KUSUMASTUTI ${ }^{3}$ \\ ${ }^{1,2}$ STIE Persada Bunda, ${ }^{3}$ Fakultas Ekonomi Universitas Trisakti \\ rudi.alhempi@gmail.com, sriyanik@gmail.com
}

\begin{abstract}
This article aims to identify the potential economic sector in Riau with data Gross Domestic Product period 2006-2012. The methods are typology Klassen, location quotient, shift share, and gravity index. The result of typology Klassen, Bengkalis, Siak and Rokan Hilir are advanced but depressed area, and others are the fast growing areas. The results of location quotient, mining and quarrying sector are dominant sector in Siak, Bengkalis, and Rokan Hilir. The agricultural sector is dominant sector in Kuantan Singingi, Indragiri Hulu, Indragiri Hilir, Pelalawan, and Rokan Hulu. Manufacturing sector is dominant sector in Dumai. Services sector is dominant sector in Pekanbaru. There are shift in the economic growth of potential sector in Riau. Economic growth had driven by the effects of provincial growth, industrial mix effect, and effect of competitive advantage. Finally, the results of Gravity Index, Bengkalis, Siak, and Pekanbaru are the center of economic growth in Riau.
\end{abstract}

Keywords: typology Klassen, location quotient, shift share, index gravity

\begin{abstract}
Abstrak. Tulisan ini bertujuan mengidentifikasi sektor ekonomi potensial di Riau dengan data Produk Domestik Regional Bruto dari 2006-2012. Metode yang digunakan adalah tipologi Klassen, location quotient, shift share, dan indeks graviti. Hasil tipologi Klassen menunjukkan bahwa pada tahun 2012, Bengkalis, Siak, dan Rokan Hilir, adalah daerah maju tapi tertekan, sedangkan yang lainnya adalah daerah berkembang cepat. Hasil location quotient menunjukkan bahwa sektor pertambangan dan penggalian merupakan sektor unggulan Siak, Bengkalis, dan Rokan Hilir. Sektor pertanian menjadi unggulan di Kuantan Singingi, Indragiri Hulu, Indragiri Hilir, Pelalawan, Rokan Hulu, dan Kampar. Sektor industri pengolahan menjadi sektor unggulan di Dumai. Sektor-sektor jasa menjadi sektor unggulan di Pekanbaru. Hasil shift share menunjukkan adanya pergeseran potensi pertumbuhan ekonomi di Riau. Pertumbuhan ekonomi didorong oleh efek pertumbuhan provinsi, efek campuran industri, dan pengaruh keunggulan kompetitif. Berdasar Indeks Graviti, Bengkalis, Siak, dan Pekanbaru, bisa menjadi pusat pertumbuhan ekonomi di Riau.
\end{abstract}

Kata kunci: tipologi Klassen, location quotient, shift share, indeks graviti

\section{Pendahuluan}

Penyebab tingginya ketimpangan pendapatan adalah perbedaan sumberdaya alam (faktor endowment) (Getachew, 2008), sumber daya manusia (Chani dkk, 2014), ketersediaan infrastruktur (Calderon dan Serven, 2014), dan kemampuan pembiayaan (Demirguc-Kunt dan Levine, 2009). Kemampuan pembiayaan yang terbatas memerlukan prioritas pembangunan agar dana pembangunan yang terbatas bisa mendapatkan manfaat yang optimal. Karena itu, diperlukan kajian untuk mengidentifikasi sektor unggulan di suatu wilayah agar pengalokasian anggaran bisa tepat sasaran. Proses pembangunan diharapkan bisa lebih cepat dengan otonomi daerah. Otonomi daerah dapat menjadi pendorong pertumbuhan ekonomi dan lajunya pertumbuhan kesejahteraan masyarakat di Indonesia. Hal ini bisa dilakukan jika pembangunan di daerah mengacu pada potensi daerah (Sukarti, 2012).

Riau adalah provinsi kelima terbesar dalam kontribusinya terhadap Produk Domestik Bruto (PDB) Indonesia sejak tahun 2009. Riau merupakan salah satu provinsi/daerah yang cukup kaya dengan hasil bumi berupa migas dan hasil perkebunan berupa kelapa sawit, nenas, kelapa, karet, dan lainnya. Sektor unggulan di Riau adalah sektor pertambangan dan penggalian; serta sektor industri pengolahan. Sektor-sektor ini sekaligus juga adalah sektor-sektor ekonomi yang memiliki daya saing cukup tinggi.

Sesuai dengan Pasal 14 UU Nomor 33 Tahun 
2004, daerah penghasil berhak mendapatkan bagian bagi hasil minyak bumi sebesar $15,5 \%$. Dengan rincian 3\% untuk provinsi tempat daerah penghasil minyak, $6 \%$ untuk daerah penghasil minyak, $6 \%$ untuk daerah lain yang masih dalam satu provinsi dan sisanya $0,5 \%$ dibagi rata untuk provinsi dan daerah yang bersangkutan, sedangkan dana bagi hasil gas bumi, 30,5\% dikembalikan ke daerah penghasil. Rincian pembagian 30,5\% tersebut; $6 \%$ untuk provinsi tempat daerah penghasil gas, $12 \%$ untuk daerah penghasil, $12 \%$ untuk daerah lain yang masih dalam satu provinsi, dan sisanya $0,5 \%$ dibagi rata untuk provinsi dan daerah yang bersangkutan. Namun, dana tersebut belum dimanfaatkan secara optimal untuk kesejahteraan rakyat.

Pembangunan daerah memerlukan perencanaan agar kesejahteraan masyarakat tercapai. Perencanaan yang efisien dan efektif memerlukan analisis yang mendalam dan mengetahui subsektor yang unggul sangat penting dalam perencanaan pembangunan ekonomi daerah. Berdasar masalah tersebut maka riset ini akan menganalisis permasalahan yang terkait dengan posisi pertumbuhan ekonomi setiap kabupaten/ kota di Riau, sektor unggulan di kabupaten/ kota di Riau, perubahan struktur di setiap sektor ekonomi di kabupaten/kota di Riau, dan interaksi antarkabupaten/kota di Riau.

Dalam literatur dinyatakan bahwa struktur perekonomian daerah dapat dibedakan atas dua sektor, yaitu sektor basis dan sektor nonbasis. Sektor basis atau unggulan adalah sektor ekonomi yang mampu memenuhi kebutuhan pasar, baik pasar domestik maupun pasar luar daerah itu sendiri. Artinya, sektor ini mampu memenuhi kebutuhan daerah sendiri maupun daerah lain. Sektor nonbasis adalah sektor ekonomi yang hanya mampu memenuhi kebutuhan daerah itu sendiri. Sektor basis menghasilkan barang dan jasa yang dapat dijual ke luar daerah, akan meningkatkan investasi dan menciptakan lapangan kerja baru. Sektor basis perlu diprioritaskan untuk dikembangkan dalam rangka mengacu pertumbuhan ekonomi daerah (Arsyad, 2010).

Potensi ekonomi daerah adalah kemampuan ekonomi yang ada di daerah yang dapat dikembangkan menjadi sumber penghidupan rakyat setempat dan dapat mendorong perekonomian daerah secara keseluruhan untuk berkembang dengan sendirinya dan berkesinambungan (Suparmoko: 2010). Strategi Pengembangan ekonomi daerah dapat dilakukan dengan beberapa cara, yaitu: (1) mengidentifikasi sektor yang memiliki potensi untuk dikembangkan dengan memperhatikan kekuatan dan kelemahan masing-masing sektor; (2) mengidentifikasi sektor yang potensinya rendah untuk dikembangkan dan mencari faktor-faktor penyebab rendahnya potensi sektor tersebut; (3) mengidentifikasi sumber daya termasuk sumber daya manusianya yang siap digunakan untuk mendukung perkembangan setiap sektor; (4) menggunakan model pembobotan terhadap variabel- kekuatan dan kelemahan untuk setiap sektor dan subsektor, selanjutnya akan ditemukannya sektor andalan yang dianggap sebagai potensi ekonomi yang dikembangkan di daerah yang bersangkutan; (5) menentukan strategi pengembangan sektor unggulan yang akan dapat menarik sektor lain untuk tumbuh sehingga perekonomian dapat berkembang dengan sendirinya secara berkelanjutan.

Maju mundurnya suatu daerah juga bergantung pada daerah-daerah lain, khususnya daerah yang berdekatan. Kerjasama antardaerah diharapkan menjadi satu jembatan yang dapat mengubah potensi konflik kepentingan antardaerah menjadi sebuah potensi pembangunan yang saling menguntungkan. Perlunya kerjasama antardaerah adalah agar berbagai masalah lintas wilayah administratif dapat terselesaikan bersama, juga agar banyak potensi yang dimiliki dapat dimanfaatkan untuk kepentingan bersama.

Penelitian yang menganalisis struktur perekonomian di Riau sudah beberapakali dilakukan, misal oleh Caska dan Riadi (2005), Asnawi (2008), dan Kornita (2008). Caska dan Riadi menggunakan data tahun 2003-2005, menghitung indeks ketimpangan Williamson dan Entopi Theil dan mengaitkannya dengan pertumbuan ekonomi. Kesimpulan mereka adalah bahwa di Riau daerah yang cepat maju dan cepat tumbuh hanya Pekanbaru. Daerah yang dikategorikan berkembang cepat adalah Pelalawan, Kuantan Singingi, Indragiri Hulu dan Siak. Untuk daerah yang maju tapi tertekan adalah Indragiri Hilir, Rokan Hulu dan Kampar, sedangkan daerah yang pertumbuhan ekonominya relatif tertinggal adalah Rokan Hilir, Dumai dan Bengkalis. Selama periode pengamatan 2003-2005, terjadi ketimpangan pembangunan yang tidak signifikan berdasarkan Indeks Williamson, sedangkan menurut Indeks Entropi Theil, ketimpangan pembangunan boleh dikatakan kecil, artinya ada pemerataan pembangunan setiap tahunnya selama periode pengamatan.

Asnawi (2008) menentukan sektor unggulan Riau dengan menggunakan Tabel Input-Output (IO). Tabel IO yang digunakan adalah Tabel I Riau tahun 2001. Hasilnya menunjukkan bahwa sektor unggulan di Riau adalah sektor industri pengolahan dan sektor bangunan dengan derajat kepekaan lebih besar dari satu Sektor industri pengolahan menjadi penggerak pertumbuhan ekonomi karena memang kontribusi sektor ini terhadap PDRB sangat besar. Industri pengolahan yang dimaksud adalah makanan minuman, bubur kertas, kimia, logam dan barang dari logam, mesin dan peralatan listrik, barang dari besi dan bahan dasar, tekstil kecuali pakaian jadi, elektronika dan komputer, serta kendaraan bermotor. Sedangkan Kornita (2008) dalam menen- 
tukan sektor unggulan menggunakan analisis LQ dengan data 2002-2006. Hasilnya menunjukkan bahwa sektor unggulan di Pekanbaru adalah sektor perdagangan dan jasa. Aktivitas ekonomi di Kampar di dorong sektor pertambangan dan penggalian. Perekonomian diBengkalis menunjukkan bahwa aktivitas perdagangan dan jasa memiliki keunggulan. Di Rokan Hilir menunjukkan bahwa sektor pertanian subsektor perkebunan adalah sektor unggulan. Sektor unggulan Indragiri Hilir adalah sektor pertanian. Pengembangan ekonomi diIndragiri Hulu adalah sektor pertanian dan industri pengolahan. Di Kuantan Singingi, sektor pertanian unggul untuk dikembangkan. Sektor industri pengolahan masih menjadi sektor unggulan diPelalawan. Aktivitas ekonomi di Siak didorong keberadaan industri pengolahan yang menjadi penggerak aktivitas ekonomi lainnya. Potensi yang ada di Dumai menunjukkan bahwa sektor unggulan daerah terutama adalah sektor perdagangan dan jasa.

Alat analisis yang digunakan adalah Location Qoutient (LQ), Shift Share (SS), Tipologi Klassen, dan Index Gravity. LQ adalah metode untuk menghitung perbandingan relatif sumbangan nilai tambah sebuah sektor di suatu daerah terhadap sumbangan nilai tambah sektor yang bersangkutan dalam skala provinsi (Tarigan, 2005). Rumusnya adalah:

$$
L Q=\frac{V A_{k}^{i} / \stackrel{\circ}{\mathrm{a}} V A_{k}}{V A_{p}^{i} / \stackrel{\circ}{\mathrm{a}} V A_{p}}
$$

Di mana $\mathrm{LQ}=$ Koefisien location quotient, $V A_{k}^{i}=$ Value added (nilai tambah) sektor i di tingkat kabupaten/kota; å $V A_{k}=$ Total value added (PDRB) di tingkat kabupaten/kota; $V A_{p}^{i}=$ Value added (nilai tambah) sektor i di tingkat provinsi; à $V A_{p}=$ Total value added (PDRB) di tingkat provinsi. Jika $\mathrm{LQ}>1$, artinya sektor yang ada di daerah tersebut merupakan sektor basis. Jika $\mathrm{LQ}<1$, hal itu menunjukkan bahwa sektor yang ada di daerah tersebut bukan merupakan sektor basis. Jika $\mathrm{LQ}=1$, hal itu menunjukkan bahwa produk domestik yang dimiliki daerah tersebut habis dikonsumsi oleh daerah tersebut.

Analisis SS digunakan untuk menganalisis pertumbuhan wilayah wilayah, dibandingkan dengan perkembangan ekonomi nasional (Nugroho dan Dahuri, 2012). Analisis SS membagi pertumbuhan wilayah dalam 3 komponenya itu pertumbuhan nasional (N), bauran industri $(\mathrm{M})$, dan keunggulan kompetitif $(C)$. Pengaruh pertumbuhan nasional disebut pengaruh pangsa; pengaruh bauran industri disebut propotional shift atau bauran komposisi; dan pengaruh keunggulan kompetitif dinamakan differential shift (Tarigan, 2005).

Untuk industri atau sektor $\mathrm{i}$ di wilayah $\mathrm{j}$ :

$$
D_{i j}=N_{i j}+M_{i j}+C_{i j}
$$

$$
\begin{aligned}
& N_{i j}=Y_{i j} r_{r} \\
& M_{i j j} Y_{i j}\left(r_{i n}-r_{n}\right) \\
& C_{i j=} Y_{i j}\left(r_{i j}-r_{i n}\right) \\
& D Y_{i j}=Y_{i j \cdot} \cdot r_{n}+Y_{i j}\left(r_{i n}-r_{r}\right)+Y_{i j}\left(r_{i j}-r_{i n}\right)
\end{aligned}
$$

Di mana $\mathrm{N}_{\mathrm{i}}=$ pertumbuhan PDRB sektor $\mathrm{i}$ kabupaten/kota di Riau dipengaruhi pertumbuhan PDRB Riau. $M_{i j}=$ Pertumbuhan PDRB sektor $i$ kabupaten/kota di Riau yang dipengaruhi oleh bauran industri Riau. $C_{i j}=$ Perubahan PDRB sektor $i$ kabupaten/kota di Riau dipengaruhi oleh keunggulan kompetitif sektor $\mathbf{i}$ di RiauY $\mathrm{ij}_{\mathrm{ij}}=$ PDRB di sektor $\mathbf{i}$ di wilayah kabupaten/kota jdi Riau. $r_{n}=$ Pertumbuhan PDRB di Riau.; $r_{\text {in }}=$ Pertumbuhan PDRB Sektor i di Riau. $r_{i j}=$ Pertumbuhan PDRB di sektor $i$ di wilayah kabupaten/kota j di Riau.

Pertumbuhan ekonomi dan pergeseran struktural suatu perekonomian daerah ditentukan oleh tiga komponen: (1) Sp digunakan untuk mengetahui pergeseran struktur perekonomian suatu daerah dengan melihat nilai PDRB daerah pengamatan pada periode awal yang dipengaruhi oleh pergeseran pertumbuhan perekonomian daerah yang lebih tinggi (provinsi). (2) Proportional Shift adalah pertumbuhan Nilai Tambah Bruto suatu sektor idibandingkan total sektor di tingkat provinsi. (3) Differential Shift (Sd), adalah perbedaan antara pertumbuhan ekonomi daerah (kabupaten) dan nilai tambah bruto sektor yang sama di tingkat provinsi.

Tipologi Klassen digunakan untuk mengetahui gambaran tentang pola dan struktur pertumbuhan ekonomi masing-masing daerah (Tarigan, 2005). Kriteria yang digunakan terdiri dari empat; Kuadran I, yakni daerah yang cepat maju dan cepat tumbuh (high income and high growth). Kuadran II, yakni daerah maju tapi tertekan (high income but low growth). Kuadran III, yakni daerah berkembang cepat (high growth but low income). Kuadaran IV adalah daerah relatif tertinggal (low growth and low income).

Model gravitasi untuk mengetahui besarnya daya tarik dari suatu potensi yang berada di suatu lokasi. Model ini digunakan untuk menganalisis kaitan potensi suatu lokasi dan besarnya wilayah pengaruh dari potensi tersebut. Interaksi diukur dari banyaknya perjalanan dari penduduk kota $\mathrm{A}$ ke kota B atau sebaliknya. berikut:

Rumus Gravitasi secara umum adalah sebagai

$$
I_{i, j}=\frac{a\left(W_{i} P_{i}\right)\left(W_{j} P_{j}\right)}{d_{i, j}^{b}}
$$

Di mana: $\mathrm{I}_{\mathrm{ij}}=$ jumlah trip antara kota i dengan kota $j, P_{i}=$ penduduk Kota $i, P_{j}=$ penduduk Kota $j$, $\mathrm{W}_{\mathrm{i}}=$ pendapatan per kapita wilayah $\mathrm{i}, \mathrm{W}_{\mathrm{i}}=$ pendapatan per kapita wilayah $\mathrm{j}, \mathrm{d}_{\mathrm{ij}}=$ jarak antara kota i dengan kota $j, b=$ menggambarkan cepatnya trip menurun seiring dengan pertambahan jarak. Nilai b dapat 
dihitung, tetapi apabila tidak maka yang sering digunakan adalah 2. a=sebuah bilangan konstanta berdasarkan pengalaman, juga dapat dihitung seperti b.

\section{Sektor Unggulan Kabupaten/Kota di Riau}

Hasil LQ menunjukkan bahwa selama kurun 2006-2012 tidak terjadi perubahan sektor unggulan di kabupaten/kota di Riau. Sektor unggulan di Kuantan Singingi adalah sektor pertanian; sektor bangunan; sektor keuangan, persewaan dan jasajasa serta sektor jasa-jasa. Sektor pertanian memiliki nilai LQ tertinggi dan subsektor yang diunggulkan adalah subsektor tanaman bahan makanan, tanaman perkebunan, dan perternakan dan hasil-hasilnya. Dominasi sektor pertanian terlihat pada perannya pada PDRB yang rata-rata mencapai $53,75 \%$. Pola seperti ini dapat mengindikasikan Kuantan Singingi masih memiliki pola yang agraris.

Hampir semua sektor ekonomi di Indragiri Hulu adalah sektor unggulan kecuali sektor pertambangan dan penggalian. Sektor pertanian merupakan sektor yang paling unggul dengan subsektor kehutanan sebagai andalan. Hasil hutan yang dihasilkan adalah berbagai jenis kayu seperti meranti, ramin, kulim, kruing, dan sebagainya. Perannya terhadap PDRB rata-rata mencapai $42,42 \%$.

Di Indragiri Hilir, semua menjadi sektor unggulan kecuali sektor pertambangan dan penggalian, dan sektor pertanian menjadi sektor yang paling unggulan. Subsektor pertanian yang dikembangkan adalah subsektor tanaman bahan makanan; subsektor tanaman perkebunan, dan subsektor perikanan. Rata-rata kontribusi sektor pertanian terhadap pembentukan PDRB selama 2006-2012 mencapai 46,13\%. Sektor sekunder dan sektor tersier juga merupakan sektor yang memiliki keunggulan; artinya, Indragiri Hilir sudah menuju daerah yang maju karena adanya perubahan pola permintaan konsumen dari produk kebutuhan pokok dan pangan ke berbagai barang dan jasa manufkatur.

Tabel 1

Sektor Unggulan Kabupaten/Kota di Riau Tahun 2006-2012

\begin{tabular}{lcc}
\hline \multicolumn{1}{c}{ Kabupaten/Kota } & 2006 & 2012 \\
\hline Kab. Kuantan Sengingi & $1,5,8,9$ & $1,5,8,9$ \\
Kab. Indragiri Hulu & $1,3,4,5,6,7,8,9$ & $1,3,4,5,7,9$ \\
Kab. Indragiri Hilir & $1,3,5,6,7,8,9$ & $1,3,5,6,8,9$ \\
Kab. Pelalawan & $1,3,8$ & $1,3,8$ \\
Kab. Siak & 2,3 & 2,3 \\
Kab. Kampar & 1,2 & 1,2 \\
Kab. Rokan Hulu & $1,3,5,8,9$ & $1,3,5,8,9$ \\
Kab. Rokan Hilir & 2 & 1,2 \\
Kab. Bengkalis & 2 & 2 \\
Kab. Kepulauan Meranti & 1,6 & $1,3,4,6,9$ \\
Kota Pekanbaru & $3,4,5,6,7,8,9$ & $4,5,6,7,8,9$ \\
Kota Dumai & $3,4,5,6,7,8,9$ & $3,4,5,6,7,9$ \\
\hline
\end{tabular}

Keterangan: (1) Pertanian, (2) Pertambangan dan Penggalian, (3) Industri Pengolahan, (4) Listrik, Gas, dan Air Bersih, (5) Bangunan, (6) Perdagangan, Hotel, dan Restoran, (7) Pengangkutan dan Komunikasi, (8) Keuangan, Persewaan, dan Jasa Perusahaan, (9) Jasa-jasa.

Sumber: Data diolah

Pelalawan merupakan kabupaten yang baru dimekarkan dengan sektor pertanian, sektor industri pengolahan, dan sektor keuangan, persewaan dan jasa perusahaan sebagai sektor unggulan. Pengembangan sektor pertanian melalui pengembangan 4 subsektor pertanian yang memiliki keunggulan komparatif terutama subsektor kehutanan. Kontribusi sektor pertanian terhadap PDRB Pelalawan rata-rata mencapai $50,71 \%$.

Siak hanya memiliki sektor pertambangan dan penggalian dan sektor industri pengolahan sebagai sektor unggulan, terutama subsektor minyak dan gas bumi (migas). Dari hasil migas ini, Siak menjadi salah satu enam kabupaten terkaya di Indonesia, dengan PDB per kapita mencapai Rp129,89 juta pada tahun 2012. Kontribusi sektor migas terhadap PDRB rata-rata mencapai $74,86 \%$ selama 2006-2012. Tingginya penerimaan dana bagi hasil seharusnya bisa digunakan untuk mendorong tumbuhnya sektor-sektor ekonomi yang lain dengan pembangunan infrastruktur dan fasilitas lainnya. Sehingga ketergantungan terhadap minyak bisa dikurangi dan sumber penerimaan asli daerah yang lain bisa ditingkatkan. 
Selama kurun waktu 2006-2012 perekonomian Kampar disokong oleh sektor pertanian dan sektor pertambangan dan penggalian. Sektor pertanian merupakan sektor potensial dengan subsektor tanaman bahan makanan; subsektor tanaman perkebunan serta subsektor peternakan dan hasil-hasilnya. Kedua sektor unggulan ini rata-rata mempunyai kontribusi terhadap PDRB sebesar $52,99 \%$ untuk sektor pertambangan dan penggalian, dan $28,54 \%$ untuk sektor pertanian.

Perekonomian Rokan Hulu didominasi oleh sektor pertanian. Subsektor yang memiliki keunggulan komparatif adalah subsektor tanaman bahan makanan; subsektor tanaman perkebunan; subsektor peternakan dan hasi-hasilnya. Sektor pertanian memberikan kontribusi terhadap PDRB rata-rata mencapai $52,57 \%$. Rokan Hulu masih dalam tahap awal untuk beralih dari sektor primer ke sektor sekunder dan tertier.

Satu-satunya sektor unggulan di Bengkalis adalah sektor pertambangan dan penggalian. Perekonomian Bengkalis mengandalkan sektor primer dan belum mampu mendorong tumbuhnya sektor-sektor ekonomi yang lainnya. Ketergantungan pada sektor pertambangan dan penggalian subsektor migas juga terlihat pada tingginya kontribusi sektor ini pada PDRB rata-rata mencapai $84,95 \%$ selama periode 2006-2012.

Sektor unggulan di Rokan Hilir adalah sektor pertambangan dan penggalian dengan subsektor unggulannya adalah sektor Minyak dan Gas Bumi. Kontribusi sektor ini terhadap PDRB rata-rata mencapai $65,88 \%$ selama periode 2006-2012. Seperti halnya kabupaten lain yang mengandalkan sektor pertambangan dan penggalian terutama migas, kabupaten ini pun belum mampu memanfaatkan sektor migas untuk mendorong pertumbuhan sektor ekonomi lain. Akibatnya, meskipun pendapatan per kapita masyarakat tinggi, pertumbuhan ekonomi kabupaten ini tergolong rendah. Di akhir 2012, sektor pertanian menjadi sektor unggulan.

Kepulauan Meranti pada awalnya adalah bagian dari Bengkalis memiliki sektor pertanian; sektor pertambangan dan penggalian; sektor perdagangan, hotel, dan restoran; dan sektor jasajasa sebagai sektor unggulan. Sektor perdagangan, hotel dan restoran merupakan sektor yang paling unggulan di Kepulauan Meranti, dengan subsektor unggulannya adalah subsektor perdagangan besar dan eceran. Kontribusi sektor perdagangan, hotel, dan restoran rata-rata mencapai $18,44 \%$ pada tahun 2006-2012. Kontribusi terbesar diberikan oleh sektor pertambangan dan penggalian yang rata-rata mencapai $38,73 \%$.

Pekanbaru memiliki keunggulan komparatif di sektor listrik, gas, dan air bersih; sektor bangunan; sektor perdagangan, hotel, dan restoran; sektor pengangkutan dan komunikasi; sektor keuangan, persewaan, dan jasa-jasa; serta sektor jasajasa. Pekanbaru sudah menjadi kota modern yang mengandalkan sektor tertier sebagai sektor penggerak ekonomi. Kota ini memang memberikan keleluasaan untuk berkembangnya sektor jasa. Kontribusi sektor jasa-jasa ini rata-rata mencapai 88,44\% dari PDRB selama periode 2006-2012.

Sama halnya dengan Pekanbaru, sektor unggulan di Dumai adalah industri pengolahan; sektor listrik, gas, dan air bersih; sektor bangunan; sektor perdagangan, hotel dan restoran; sektor pengangkutan dan komunikasi; sektor keuangan, persewaan, dan jasa-jasa; serta sektor jasa-jasa. Sektor industri pengolahan merupakan sektor paling unggul dengan subsektor unggulannya adalah subsektor industri migas. Kontribusi sektor industri pengolahan terhadap PDRB rata-rata mencapai $48,94 \%$. Hasil ini juga menunjukkan adanya perubahan struktual di Dumai di mana pada periode 2000-2005 sektor yang paling unggul adalah sektor pengangkutan dan komunikasi (Rubiati, 2008).

Dalam analisis shift-share (SS), perubahan atau pergeseran perekonomian dapat dilihat ketiga efek pembentuknya. Ketiga efek tersebut, antara lain, adalah efek pertumbuhan nasional, efek bauran industri, dan efek keunggulan kompetitif. Selama periode 2006-2012, terjadi perubahan perekonomian Kuantan Singingi di seluruh sektor, dengan peningkatan terbesar terjadi pada sektor pertanian. Peningkatan nilai PDRB di seluruh sektor lebih banyak disokong oleh kebijakan pemerintah provinsi dan pemerintah pusat untuk memajukan sektor tersebut seperti yang tercermin oleh kontribusi yang diberikan oleh efek pertumbuhan provinsi yang positif di seluruh sektor. Efek bauran industri memiliki nilai yang positif, kecuali pada sektor pertambangan dan sektor pertanian. Artinya, seluruh sektor kecuali sektor pertambangan dan penggalian dan sektor pertanian sudah memiliki industri yang secara regional provinsi berkembang pesat dan struktur industri tersebut sudah cocok berada di Kuantan Singingi.

Selama periode 2006-2012, terjadi pergeseran perekonomian Indragiri Hulu di seluruh sektor, dengan peningkatan terbesar terjadi pada sektor industri pengolahan. Di sektor industri pengolahan terjadi peningkatan sebesar Rp542,929 Juta. Berarti, sektor ini menjadi menyokong terbesar perubahan PDRB di kabupaten ini.

Seluruh sektor di Indragiri Hilir mengalami peningkatan nilai PDRB. Sektor pertanian mempunyai peningkatan nilai PDRB tertinggi dibandingkan sektor lainnya. Sektor pertanian juga memiliki kontribusi positif pada efek pertumbuhan provinsi, efek bauran industri, dan efek keunggulan kompetitif. Artinya, sektor pertanian ini disokong oleh kebijakan pemerintah pusat dan provinsi untuk meningkatkan outputnya.Industri yang berada pada sektor tersebut berkembang pesat dan struktur industri tersebut 
cocok berada di Indragiri Hilir serta memiliki daya saing.

Secara agregat, perekonomian Pelalawan mengalami pergeseran di seluruh sektor dengan peningkatan terbesar terjadi pada sektor pertanian. PBD sektor pertanian meningkat sebesar Rp 468.036 juta dibandingkan tahun 2006. Peningkatan nilai PDRB sektor pertambangan dan penggalian juga mengalami peningkatan nilai PDRB yang disebabkan oleh kontribusi positif dari efek pertumbuhan provinsi dan efek keunggulan provinsi, sedangkan efek bauran industri memberikan kontribusi negatif terhadap pembentukan PDRB sektor pertambangan dan penggalian.

Perekonomian Siak secara agregat mengalami pergeseran di seluruh sektor, dengan peningkatan terbesar terjadi di sektor industri pengolahan sebesar Rp 762.376 juta. Di tahun 2012, terjadi penurunan yang cukup signifikan nilai PDRB di sektor pertambangan dan penggalian, penyebab penurunan nilai PDRB tersebut dikarenakan kontribusi negatif dari efek bauran industri dan efek keunggulan kompetitif, sehingga pembentukkan output sektor tersebut hanya disokong oleh efek pertumbuhan provinsi. Prawira dan Hamidi (2013) juga menyatakan bahwa struktur perekonomian Siak bergeser dari sektor primer menuju ke sektor sekunder dan tersier. Penurunan tersebut juga disebabkan berfluktuasinya harga minyak yang merupak sektor andalan Siak.

Secara agregat, perekonomian Kampar mengalami pergeseran di seluruh sektor dengan peningkatan terbesar terjadi pada sektor pertanian. Sektor pertanian mengalami peningkatan angka PDRB sebesar Rp 842.841 juta pada tahun 2012 dibandingkan tahun 2006. Efek bauran industri selama periode tersebut memberikan kontribusi positif kecuali sektor pertambangan dan penggalian dan sektor pertanian.

Perekonomian Rokan Hulu secara agregat mengalami perubahan di seluruh sektor, kecuali sektor pertambangan dan penggalian, dengan peningkatan terbesar terjadi pada sektor pertanian. Sektor pertanian menjadi unggulan karena ketiga efek yang membentuk nilai PDRB sektor pertanian memberikan kontribusi positif, sehingga selain ada kebijakan yang mampu mendorong, kemampuan berspesialisasi, sektor tersebut juga memiliki daya saing.

Perekonomian Bengkalis mengalami pergeseran di seluruh sektor di mana sektor pertambangan dan penggalian merupakan sektor yang paling besar peningkatan PDRBnya. Besarnya perubahan disebabkan oleh efek pertumbuhan provinsi serta efek keunggulan kompetitif yang memberikan kontribusi positif, sedangkan efek bauran industri memberikan kontribusi negatif terhadap pembentukan nilai PDRB. Berarti, peningkatan output sektor pertambangan dan penggalian lebih banyak didorong oleh kebijakan pemerintah pusat maupun pemerintah provinsi serta sektor tersebut memiliki daya saing, walaupun industri yang berada pada sektor pertambangan dan penggalian pada tingkat provinsi belum berkembang pesat.

Perekonomian Rokan Hilir mengalami perubahan di seluruh sektor, dengan peningkatan terbesar tetap terjadi pada sektor pertanian yang disebabkan ketiga efek dalam membentuk nilai PDRB sektor pertanian seluruhnya memberikan kontribusi positif. Semua sektor di Rokan Hilir didorong oleh kebijakan pemerintah pusat dan pemerintah provinsi, dan hanya terdapat 2 sektor yang memiliki daya saing yang konsisten, yaitu sektor pertanian dan sektor industri pengolahan, serta hampir seluruh sektor secara konsisten memiliki spesialisasi.

Kepulauan Meranti mengalami pergeseran perekonomian di seluruh sektor, kecuali sektor pertambangan dan penggalian. Perubahan nilai PDRB terbesar terjadi di sektor perdagangan, hotel, dan restoran. Jika dilihat berdasarkan komponen pembentuk nilai PDRB, efek pertumbuhan provinsi dan efek bauran industri memberikan kontribusi positif namun efek keunggulan kompetitif memberikan kontribusi negatif. Berarti, peningkatan output pada sektor perdagangan, hotel dan restoran lebih banyak didorong oleh kebijakan pemerintah pusat dan pemerintah provinsi serta industri yang bergerak pada sektor tersebut. Sektor ini berkembang pesat dan tepat berlokasi pada Kepulauan Meranti walaupun tidak memiliki daya saing. Terdapat beberapa sektor yang memiliki nilai positif untuk ketiga efek pembentuk outputnya, yaitu sektor pertanian; sektor industri pengolahan; sektor listrik, gas, dan air bersih; sektor pengangkutan dan komunikasi; serta sektor jasa-jasa. Artinya, kelima sektor tersebut didukung oleh kebijakan pemerintah, memiliki daya saing serta sudah cocok berlokasi di Kepulauan Meranti atau sudah mampu berspesialisasi.

Perekonomian Pekanbaru mengalami pergeseran di seluruh sektor, dengan peningkatan terbesar terjadi pada sektor perdagangan, hotel dan restoran. Peningkatan nilai PDRB tersebut disebabkan karena kontribusi positif dari ketiga efek pembentuknya. Berarti sektor perdagangan, hotel, dan restoran sudah didukung oleh kebijakan pemerintah, mampu berspesialisasi serta memiliki daya saing. Selain sektor perdagangan, hotel, dan restoran, terdapat sektor lainnya yang secara konsisten memiliki nilai positif di ketiga efek, yaitu sektor pengangkutan dan komunikasi.

Perekonomian Dumai juga mengalami perubahan di seluruh sektor. Sama halnya dengan Pekanbaru, Dumai memiliki sektor dengan perubahan struktur tertinggi adalah sektor perdagangan, hotel, dan restoran. Peningkatan nilai PDRB dikarenakan kontribusi positif efek pertumbuhan provinsi, efek bauran industri, serta efek keunggulan kompetitif. 
Seluruh sektor di Dumai lebih banyak didorong oleh kebijakan pemerintah pusat dan pemerintah provinsi, seperti yang ditunjukkan oleh nilai efek pertumbuhan provinsi yang positif di semua sektor. Sedangkan untuk efek bauran industri dan efek keunggulan kompetitif memberikan kontribusi yang bervariasi.

Analisis Tipologi Klassen membandingkan pertumbuhan setiap kabupaten/kota dengan pertumbuhan Riau tahun 2006 dan tahun 2012. Pada tahun 2006 dan 2012, terdapat 6 kabupaten/ kota yang berada pada kuadran pertumbuhan ekonomi tinggi tetapi pertumbuhan pendapatan per kapita masih lebih rendah dan termasuk daerah yang berkembang. Kabupaten/kota tersebut adalah Pekanbaru, Kuantan Singingi, Indragiri Hilir, Pelalawan, Indragiri Hulu, Rokan Hulu. Pekanbaru merupakan kota perdagangan dan jasa, termasuk sebagai kota dengan tingkat pertumbuhan, migrasi, dan urbanisasi yang tinggi. Kota ini menjadi tujuan penduduk sekitar untuk mencari penghasilan yang lebih tinggi. Tetapi, sebagian besar dari mereka berada di sektor informal yang belum mampu memberikan pendapatan yang tinggi pada sebagian besar penduduknya. Kuantan Singingi, Indragiri Hilir, Pelalawan, Indragiri Hulu, dan Rokan Hulu, semuanya mengandalkan sektor pertanian. Tingginya pertumbuhan yang ditopang sektor pertanian ternyata belum mampu mensejahterakan masyarakatnya. Harga jual produk pertanian tidak stabil. Saat panen melimpah, harga jual produk cenderung mengalami penurunan. Subsektor perkebunan, terutama kelapa sawit, menjadi andalan di Kuantan Singingi, Indragiri Hilir, dan Rokan Hulu; sedangkan subsektor kehutanan menjadi pendorong pertumbuhan di Pelalawan dan Indragiri Hulu.

Tabel 2. 1

Tipologi Klassen Kabupaten/Kota di Riau

\begin{tabular}{ccc}
\hline Laju Pertumbuhan Tinggi & Perdapatan per kapita rendah & Pendapatan per kapita tinggi \\
& $\begin{array}{c}\text { Daerah berkembang cepat } \\
\text { Pekanbaru, Kuantan Singingi, } \\
\text { Indragiri Hilir, Pelalawan, Indragiri } \\
\text { Hulu, Rokan Hulu }\end{array}$ & $\begin{array}{c}\text { Daerah cepat maju dan cepat } \\
\text { tumbuh }\end{array}$ \\
\hline Laju Pertumbuhan Rendah & $\begin{array}{c}\text { Daerah relatif tertinggal } \\
\text { Dumai, Kampar }\end{array}$ & $\begin{array}{c}\text { Daerah maju tapi tertekan } \\
\text { Siak, Bengkalis, Rokan Hilir }\end{array}$ \\
& 2012 & \\
Laju Pertumbuhan Tinggi & $\begin{array}{c}\text { Daerah berkembang cepat } \\
\text { Pekanbaru, Kuantan Singingi } \\
\text { Indragiri Hilir, Pelalawan } \\
\text { Indragiri Hulu, Rokan Hulu } \\
\text { Dumai, Kampar, Kepulauan Meranti }\end{array}$ & $\begin{array}{c}\text { Daerah cepat maju dan cepat } \\
\text { tumbuh }\end{array}$ \\
\hline Laju Pertumbuhan Rendah & Daerah relatif tertinggal & $\begin{array}{c}\text { Daerah maju tapi tertekan } \\
\text { Siak, Rokan Hilir, Bengkalis }\end{array}$ \\
\hline
\end{tabular}

Dumai mengalami pergeseran kuadran dari daerah relatif tertinggal ke daerah berkembang pesat. Dumai mempunyai pertumbuhan pendapatan per kapita yang rendah dan pertumbuhan ekonomi yang bergeser rendah ke tinggi. Sektor yang menjadi penyumbang terbesar PDRB adalah sektor industri pengolahan, terutama industri pengilangan minyak bumi. Pertumbuhan ekonomi tinggi yang diperoleh dari industri minyak belum banyak berimbas pada pertumbuhan pendapatan per kapita masyarakat.

Kampar yang pada awalnya termasuk daerah yang tertinggal berhasil bergeser menjadi daerah yang berkembang pesat. Kampar mengandalkan sektor pertambangan dan penggalian, terutama penggalian sebagai sektor andalan tetapi penggalian yang ada adalah galian $C$. Sektor ini belum mampu memberikan peningkatan pendapatan per kapita masyarakat pada khususnya dan pertumbuhan ekonomi pada umumnya.

Kepulauan Meranti sebagai daerah pemekaran baru mampu mendorong pertumbuhan ekonomi dan peningkatan pendapatan masyarakat, sehingga masuk ke daerah yang berkembang pesat. Tetapi, potensi perkebunan masih diperdagangkan dalam bentuk bahan baku ke luar daerah Riau dan belum dimaksimalkan menjadi industri hilir, sehingga belum membawa nilai tambah yang mendampak luas bagi kesejahteraan masyarakat lokal.

Tiga daerah yang mengandalkan sektor pertambangan subsektor migas, yaitu Siak, 
Bengkalis, dan Rokan Hilir, termasuk dalam daerah maju tetapi tertekan. Daerah ini mempunyai pendapatan per kapita tinggi, tetapi dengan pertumbuhan ekonomi rendah. Bahkan, Siak dan Bengkalis selama tahun 2011-2012 mempunyai pertumbuhan ekonomi negatif karena fluktuasi harga minyak bumi. Bengkalis pada tahun 2010 sempat menjadi daerah yang cepat maju dan cepat tumbuh, tetapi turun posisi karena fluktuasi harga minyak. Ketergantungan kepada subsektor migas yang sangat tinggi membuat daerah-daerah ini terlena dan mengabaikan untuk mendorong sektorsektor yang lain.

Pembangunan wilayah dilakukan dengan melihat keterkaitan antarwilayah dengan mencari pusat-pusat pertumbuhan yang mempunyai daya interaksi yang kuat. Mencari daerah yang memiliki interaksi yang kuat antarkabupaten/kota di Riau dilakukan dengan indeks graviti. Berdasarkan indeks graviti yang paling tinggi di setiap kabupaten/ kota terlihat pola interaksi seperti pada Gambar 1. Siak, Bengkalis, dan Pekanbaru, bisa menjadi pusat pertumbuhan di Riau. Siak mempunyai saling interaksi yang kuat dengan Kepulauan Meranti. Dua kabupaten yang terkait kuat dengan Siak adalah Bengkalis dan Pelalawan. Pembangunan di Bengkalis akan bisa menjadi daya tarik bagi Dumai dan Rokan Hilir. Rokan Hulu lebih terkait dengan Kampar. Kampar sendiri mempunyai saling keterkaitan yang kuat dengan Pekanbaru. Dan Kuantan Singingi mempunyai keterikatan kuat dengan Pekanbaru. Dua kabupaten yang terlepas tetapi saling terkait kuat adalah Indragiri Hulu dan Indragiri Hilir. Sebagai dua kabupaten yang berbatasan dengan Jambi, kemungkinan keduanya tidak terkait kuat dengan kabupaten/kota yang ada di Riau. Kedua kabupaten ini mempunyai sektor unggulan yang sama, yaitu sektor pertanian subsektor perkebunan di Indragiri Hilir dan subsektor kehutanan di Indragiri Hulu, serta sektor industri pengolahan nonmigas.

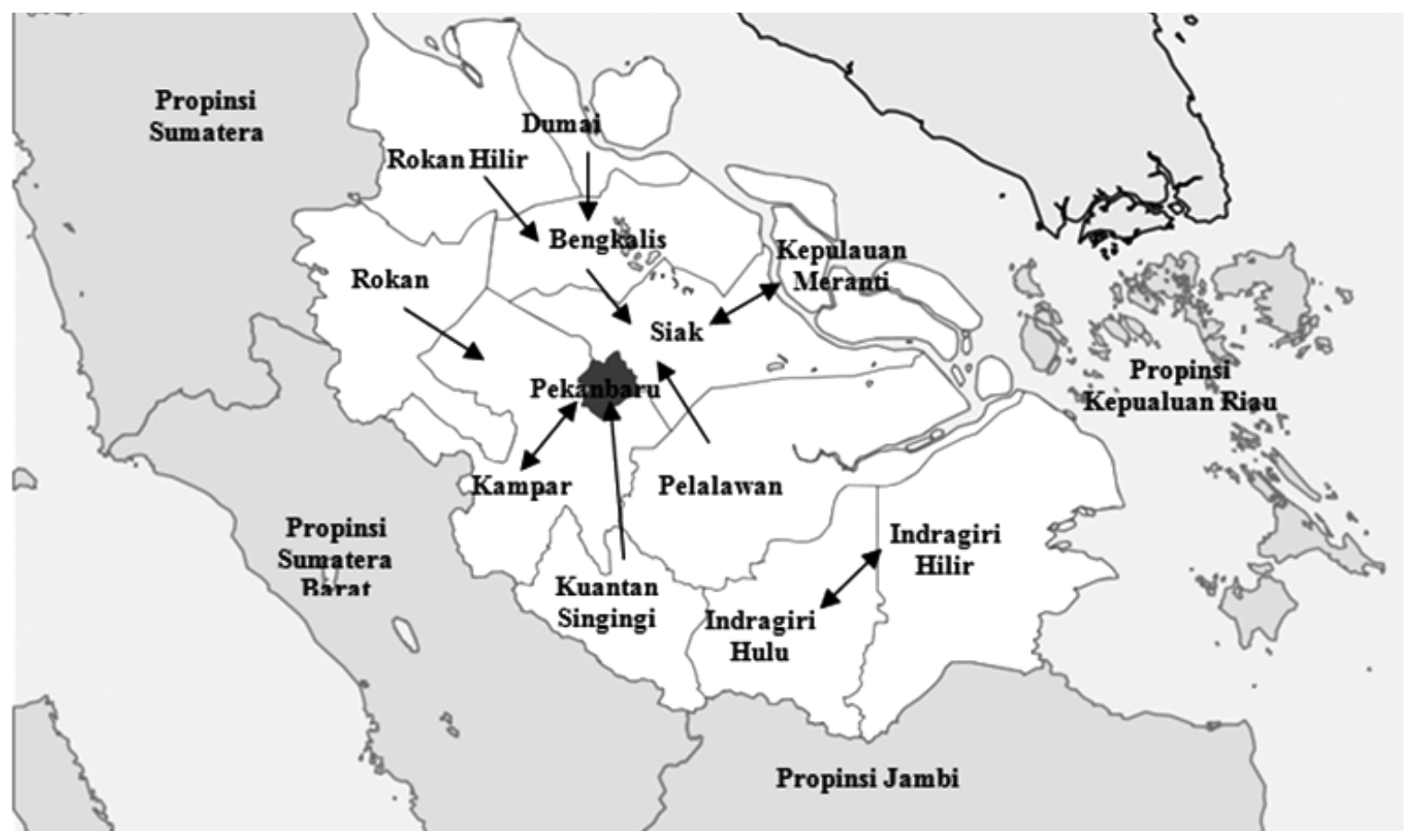

Gambar 1

Pola Interaksi antarkota/Kabupaten di Riau Berdasarkan Angka Indeks Gravity Tertinggi dari Setiap Kota/ Kabupaten

Berdasarkan angka indeks graviti tertinggi, maka akan didapatkan pola interaksi seperti terlihat pada Gambar 2. Terdapat tiga kota yang bisa menjadi pusat pertumbuhan di Riau, yaitu Bengkalis, Siak, dan Pekanbaru. Strategi pembangunan Riau bisa dipusatkan pada pembangunan pusat pertumbuhan. Dana perolehan migas digunakan untuk membangun sektor-sektor ekonomi lainnya. Dengan mengembangkan sektor yang jadi unggulan dan berdaya saing, wilayah ini akan bisa menarik wilayah lain untuk berkembang. Hal ini sedikit berbeda dengan hasil penelitian Sari dan Pujiyono (2013) yang menyatakan bahwa salah satu sektor unggulan di Riau adalah sektor pertanian, selain sektor pertambangan dan penggalian. Sektor pertanian memang menjadi unggulan di beberapa kabupaten tetapi kabupaten tersebut belum bisa menjadi pusat pertumbuhan yang mampu menarik wilayah lain.

Terdapat 5 kabupaten/kota yang terkait saling 


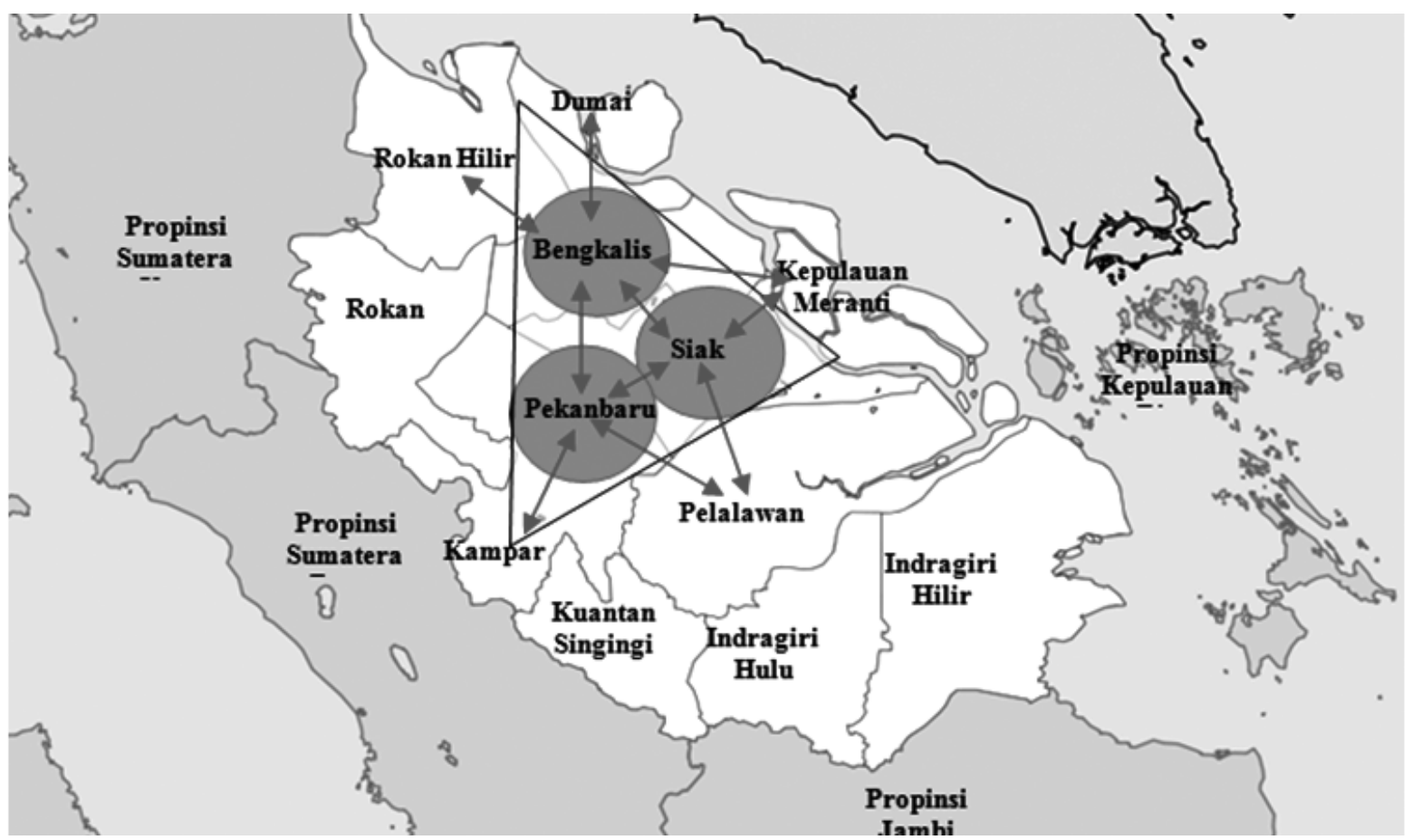

Gambar 2

Pola interaksi terkuat antar kota/kabupaten di Riau berdasar 10 angka indeks tertinggi

terkait erat dengan Bengkalis, yaitu Pekanbaru, Siak, Dumai, Rokan Hilir, dan Kepulauan Meranti. Terdapat 4 kabupaten/kota terkait erat dengan Siak, yaitu Bengkalis, Pekanbaru, Pelalawan, dan Kepulauan Meranti. Dan terdapat 4 kabupaten/kota yang terkait erat dengan Pekanbaru, yaitu Bengkalis, Siak, Kampar, dan Pelalawan, sedangkan Rokan Hulu, Kuantan Sengingi, Indragiri Hulu, dan Indragiri Hilir masih belum mempunyai keterkaitan erat dengan 3 pusat pertumbuhan yang ada.

Berdasarkan pusat-pusat pertumbuhan tersebut maka bisa disusun strategi pembangunan di Riau. Perumusan strategi dan arah kebijakan pembangunan Provinsi Riau selain pencapaian tujuan dan sasaran dalam visi dan misi juga memerhatikan: (1) pencapaian prioritas dan sasaran pembangunan nasional, seperti terhadap MDGs, Standar Pelayanan Minimal, pengentasan kemiskinan, penciptaan lapangan kerja; (2) pencapaian perioderisasi RPJP Provinsi Riau tahap ke-3; (3) pengembangan sektor/bidang yang terkait keunggulan kompetitif daerah; serta (4) permasalahan-permasalahan pembangunan yang dirangkum dalam isu strategis daerah (Bappeda Riau, 2014).

Strategi dan arah kebijakan pembangunan Provinsi Riau difokuskan pada: (1) peningkatan pembangunan infrastruktur terutama jalan untuk meningkatkan koneksitas antarwilayah; (2) pelayanan pendidikan dan kesehatan untuk peningkatan kualitas sumberdaya manusia; (3) pembangunan pertanian dan perkebunan; (4) peningkatan kualitas aparatur pemerintahan; (5) peningkatan daya saing perekonomian.

Untuk bisa mendorong pembangunan sektor unggulan juga diperlukan peran pemerintah (pusat dan daerah), swasta, dan masyarakat. Sebagaimana dikemukakan oleh Hariyanto dan Mukhsin (2008) bahwa faktor yang memengaruhi pengembangan sektor potensial dalam upaya peningkatan PAD adalah faktor pemerintah, masyarakat, dan swasta. Pemerintah perlu menciptakan iklim investasi dengan menyediakan infrastruktur untuk mendukung investasi. Investasi inilah yang nantinya diharapkan bisa mendorong pengembangan sektor potensial di Riau. Peningkatan PAD menjadi prioritas sumber pendapatan utama bagi kabupaten/kota di Riau sehingga tidak terlalu tergantung pada penerimaan sektor migas (Pemprov Riau, 2014).

\section{Simpulan dan Saran}

Simpulan penelitian ini adalah: (1) Hasil LQ menunjukkan bahwa sektor pertambangan dan penggalian menjadi sektor unggulan di Siak, Bengkalis, dan Rokan Hilir. Sektor pertanian menjadi unggulan di Kuantan Singingi, Indragiri Hulu, Indragiri Hilir, Pelalawan, dan Rokan Hulu. Sektor perdagangan, hotel, dan restoran, sektor industri pengolahan, dan sektor pengakutan dan komunikasi menjadi sektor unggulan di Pekanbaru. Sektor-sektor ini diharapkan dapat memenuhi kebutuhan dalam maupun luar daerah. Sektor industri pengolahan menjadi sektor unggulan di 
Dumai. Kepulauan Meranti menjadikan sektor perdagangan, hotel, dan restoran sebagai sektor unggulan. Pengembangan kabupaten/kota di Riau selanjutnya diarahkan untuk lebih meningkatkan keterkaitan antardaerah; (2) Hasil shift-share menunjukkan pertumbuhan ekonomi di kabupaten/ kota di Riau didorong oleh efek pertumbuhan provinsi, efek bauran industri, dan efek keunggulan kompetitif. Setiap kabupaten/kota mempunyai sektor yang berdaya saing yang berbeda-beda dengan faktor pendorong yang berbeda-beda pula; (3) Berdasar hasil tipologi Klassen, pada tahun 2010, Bengkalis masuk kategori daerah yang cepat maju. Siak dan Rokan Hilir termasuk daerah maju tapi tertekan. Pekanbaru, Kuantan Singingi, Indragiri Hilir, Indragiri Hulu, Pelalawan, Rokan Hulu, dan Dumai, termasuk dalam kategori daerah yang berkembang cepat. Kampar dan Kepulauan Meranti tergolong daerah yang relatif tertinggal; (4) Dari hasil Indeks Graviti dapat disimpulkan bahwa Bengkalis, Siak, dan Pekanbaru, mempunyai keterkaitan yang erat sehingga menjadi pusat pertumbuhan ekonomi di Riau. Bengkalis menarik Dumai, Rokan Hilir, dan Kepulauan Meranti. Siak menarik Kepulauan Meranti dan Pelalawan. Pekanbaru menarik Pelalawan dan Kampar.

Berdasarkan kesimpulan tersebut, kebijakan ekonomi yang variatif dan aplikatif harus diwujudkan agar semua sektor memiliki kesempatan yang sama untuk berkembang, tidak hanya terfokus pada satu sektor tertentu saja mengingat potensi sektor-sektor ekonomi lainnya seperti pertanian, perdagangan, bangunan dan jasa-jasa belum berada pada peran yang optimal.

\section{Daftar Pustaka}

Arsyad, Lincoln (2010). Ekonomi Pembangunan. Edisi keempat. Lembaga Penerbitan STIE YKPN Yogyakarta

Asnawi, John (2008). "Sektor Unggulan Perekonomian Riau". Jurnal Teroka Riau. 8:104-. 107

Badan Pusat Statistik Provinsi Riau (2013). Pendapatan Regional Kabupaten/Kota menurut Lapangan Usaha 2008-2012.

Badan Pusat Statistik Provinsi Riau (2013). Produk Domestik Regional Bruto Riau menurut Lapangan Usaha 2008-2012.

Badan Pusat Statistik Provinsi Riau (2012), Riau dalam Angka Tahun 2012

Badan Pusat Statistik Provinsi Riau (2013), Riau dalam Angka Tahun 2013.

Badan Perencanaan Pembangunan Daerah Provinsi Riau (2014). Rencana Pembangunan Jangka Menengah Daerah (RPJMD) Provinsi Riau Tahun 2014-2019.

Caska dan RM. Riadi (2005), "Pertumbuhan dan Ketimpangan Pembangunan Ekonomi
Antar Daerah di Provinsi Riau" Jurnal Pembangunan Ekonomi Daerah (diunduh dari http://www.scribd.com/doc/52587519/ Jurnal-Pembangunan-Ekonomi-Daerah tgl 15 September 2011).

Calderon, C. A., Luis Serven (2014). "The Effects of Infrastructure Development on Growth and Income Distribution" Annals of Economics and Finance, Volume 15 (2): 521534.

Chani, M., Sajjad Jan, Zahid Pervaiz, Amatul Chaudhary (2014). "Human capital inequality and income inequality: testing for causality" Quality \& Quantity, Vol. 48 (1): 149-156.

Demirguc-Kunt, A., Ross Levine (2009). "Finance and Inequality: Theory and Evidence" NBER Working Papers No. w15275, National Bureau of Economic Research, Cambridge.

Getachew, Yoseph (2008). "Public Capital, Income Distribution and Growth" MERIT Working Papers No.056, United Nations University - Maastricht Economic and Social Research Institute on Innovation and Technology (MERIT).

Hariyanto, A., Dadan Mukhsin (2008). "Identifikasi Sektor Potensial Penggerak Kegiatan EkonomiKecamatan Kurang Berkembang di Kab. Tangerang" MIMBAR, Vol. XXIV, No. 1 (Januari - Juni 2008): 59-67

Kornita, Srie (2008). "Analisis Sektor Ekonomi Unggulan di Provinsi Riau," Warta ISEI, Edisi 08 Tahun II Maret-April 2008. Pekanbaru.

Nugroho, Iwan dan Rokhmin Dahuri (2012). Pembangunan Wilayah: Perspektif Ekonomi, Sosial, dan Lingkungan. Jakarta: LP3ES

Pemerintah Provinsi Riau (2014). Rencana Kerja Pembangunan Daerah (RKPD) Provinsi Riau Tahun 2015

Prawira, Yudha dan Wahyu Hamidi (2013), "Transformasi Struktur Ekonomi Kabupaten Siak Tahun 2001-2010" Jurnal Ekonomi, Vol. 21(1): $1-21$

Rubiati (2008). "Analisa Pengembangan Ekonomi Kota Dumai Provinsi Riau Tahun 2000-2005" Skripsi. Sekolah Tinggi Ilmu Ekonomi Keuangan dan Perbankan Indonesia (STEKPI).

Sari, Norma Rita; Arif Pujiyono (2013). "Analisis Pertumbuhan Ekonomi dan Ketimpangan Pendapatan Antar Provinsidi Indonesia Tahun 2004-2010" Diponegoro Journal of Economics, Vol. 2 (3): 1-15.

Sukarti, Ahmad. (2012). "Otonomi Daerah sebagai Instrumen Pertumbuhan Kesejahteraan dan Peningkatan Kerjasama Antardaerah" MIMBAR Vol. XXVIII, No. 1: 39-46.

Suparmoko, M. (2010), Ekonomi Publik: untuk Keuangan dan Pembangunan Daerah, Edisi Pertama, Yogyakarta: Andy.

Tarigan, Robinson (2005). Ekonomi Regional: Teori dan Aplikasi (Edisi Revisi). Jakarta: Bumi Aksara. 